INTERNATIONAL JOURN AL OF RESEARCHES IN BIOSCIENCES, AGRICULTURE AND TECHNOLOGY (c) VISHWASHANTI MULTIPURPOSE SOCIETY (Global Peace Multipurpose Socie ty) R. No. MH-659/13 (N) www.vmsindia.org

\title{
STUDY ON PHYSICO-CHEMICAL PARAMETERS OF MANMADE RESERVOIR FROM PATHARDI TEHSIL, (M.S.) INDIA
}

\author{
B. B. Tilekar \\ Dada Patil Rajale College, Adinathnagar Tal-PathardiDist-Ahmednagar- (M.S.). \\ babatilekar@gmail.com
}

\begin{abstract}
:
The quality of water is concern for mankind since it is directly linke d with human welfare. The present study was undertaken to investigate the physical and chemical entities comprising of eleven parameters, which will help understanding the status of damwater. Water sample collected Moharireservoirlocated in eastern part of PathardiTahasil, District-Ahmednagar (MS). The physio-chemical parame ters are Atmosphe ric Te mpe rature (AT), Water Temperature (WT),PotentiaHydrogenii(pH), Electrical Conductivity(EC), Total Dissolve Solid(TDS), Acidity(Acid), Alkalinity(Alk),Carbon dioxide $\left(\mathrm{CO}_{2}\right)$, Dissolve Oxygen(DO), Total Hardness(TH), Chloride (Chlo) were mentioned on monthly basis for period of one time annual cycle i.e. January 2014 to December 2014. The result revealed that the reservoir water is safe for human use.
\end{abstract}

Keywords: Investigate, Moharireservoir, Parame ters.

\section{Introduction}

Artificial dams are constructed in some rivers for providing irrigation to crop fields. The increase of human population beyond the carrying capacity of a watershed with respect to the resources available with the ecosystem balance in the watershed, causing pollution and other environmental problems. The problem of pollution in the fresh water systems in our country is mainly because of anthropogenic activities (Haniffa et al., 1993)1. Domestic and industrial effluents pollute the majority of freshwater recourses in India (Jain et al., 1995) $)^{2}$.

Environment is a system of physical, chemical and biological factors in dynamic equilibrium. The environment can be defined as physical surrounding of which part on he is dependent for his activities like physiological functioning, production and consumption. The physical environment stretches from air, water, plants and e cosys tems.

\section{STUDY AREA:}

The present study was conducted for one year i.e. January 2014 to December 2014 through the monthly sampling of Moharire servoir. Moharireservoirlocated in southern part of $\left(\begin{array}{llllll}190 & 9^{\prime} & \mathrm{N}, & 750 & 10^{\prime} & \mathrm{E}\end{array}\right)$ PathardiTahasil, which falls in Arangaon range of Balaghat, Dis trict: Ahmed nagar. The reservoir is situated in southern part of Tehsil, which is hilly area with drought condition. The Mohari reservoir is Minor irrigation project type of reservoir near Pathardi, about $9 \mathrm{~km}$ from PathardiTehsil. It is constructed during the year 1974 having height of 14.35 meter. The catchment are is 9.00 square miles, which stores $92.00 \mathrm{mcft}$ water and area under submergence is 350 acres.

The diversity of zooplanktons is depending on water quality of reservoir. The zooplanktons is microscopic free living floating organism, which occupy a central position between the autotrophy and other heterotrophs and from an important link in aquatic fold web. Human life is living pattern without the presence of aquatic animals.

\section{Materials and Methods:}

The water samples were collected monthly on the basis the physio-chemical parameters are Atmospheric Temperature (AT), Water Temperature (WT), PotentiaHydrogenii (pH), Electrical Conductivity(EC), Total Dissolve Solid(TDS), Acidity(Acid), Alkalinity(Alk), Carbon dioxide $\left(\mathrm{CO}_{2}\right)$, Dissolve Oxygen(DO), Total Hardness(TH), Chloride (Chlo)were carried out on field. The analysis was carried out by slandered method as described by (Trivedy et al,1986) ${ }^{3}$ (Maiti :2006) 4

\section{Results and Discussion:}

\section{AtmosphericTemperature (AT)}

Atmospheric temperature of surface water ranges from $23.2^{\circ} \mathrm{C}$ to $42.1^{\circ} \mathrm{C}$ during the study period .Minimum $\left(27.0^{\circ} \mathrm{C}\right)$ and Maximum $\left(42.1^{\circ} \mathrm{C}\right)$ atmospheric temperature (AT) were recorded during the winter and summer season respectively. The water temperature was maximum during summer $\left(39.1^{\circ} \mathrm{C}\right)$ and minimum during winter(22.20C). The result show that water temperature varies with the atmospheric temperature, similar result were found by (Singhai et al; 1990) ${ }^{5}$ also found by a direct relationship between air and water temperature. During the summer season, solar 
radiation is and clear sky condition enhanced the atmospheric temperature. Whe re the during monsoon season, rainfall and cloudy-skies brought down the atmospheric temperature and subsequently the water temperature to minimum (Goel P.K., 1997), 6

\section{Water Temperature (WT)}

Water temperature is of enormous significance as it regulates various abiotic characteristics and biotic activities of an aquatic ecosystem which is recognized by many authors (Sharma and Sarang, 2004) ${ }^{7}$, (Radhika et al., : $2004)^{8}$. It is clear from there were no significant variations in surface-water temperature across stations and over years during the pre-monsoon and the north east monsoon in the Lake, whereas the differences in surface water temperature across the stations and over the years were significant during the southwest monsoon. A comparison of the average of surface-water temperature of the three-year period showed that the variations in temperature across the different stations were insignificant

pH

$\mathrm{pH}$ value of all sample lies in the range of 7.5 to 8.8 are slightly alkaline and suitable to irrigation purpose i.e. there is no alkalinity hazard. The $\mathrm{pH}(7.5$ to 8.1$)$ during winter and higher value (8.1 to 8.8) during summer. $\mathrm{pH}$ balance in an ecosystem is maintained when it is within the range of 5.5 to8.5 (Chandrasekhar et al., 2003 $)^{9}$. Similarly higher $\mathrm{pH}$ range is also recorded by (Zafer;1966) ${ }^{10}$ observed that $\mathrm{pH}$ of the water appear to be dependent upon the relatives quantities of calcium carbonite and bicarbonates, being alkaline when disposal of wastes also bring about changes in the $\mathrm{pH}$.

\section{Electrical Conductivity(EC)}

Electrical Conductivity(EC) is a measure of the salt content of wate $r$ in the form of ion. EC value ranges from $189 \mu \mathrm{S} / \mathrm{cm}$. to $294 \mu \mathrm{S} / \mathrm{cm}$. With an average of $235 \mu \mathrm{S} / \mathrm{cm}$. The month wise value shows the minimum during December. The concentration of Ec increase during summer and reaches maximum in jully. The increase in EC during pre monsoon period may be due to evaporation. This is in agreement with result obtained by (Shankar et al: 2002) ${ }^{11}$.

\section{Total Dissolve Solid (TDS)}

Total Dissolve Solid (TDS) are various kinds of minerals substances present I water. Some dissolve organic matter may also contribute to total dissolve solid.TDSA value ranges from 105 $\mathrm{mg} / 1$ to $160 \mathrm{mg} / 1$. The season wise value show the minimum during winter. The concentration of TDS in water gives an idea about suitability of this water for various uses including potable water (Trivedy: 1995)12. All the values of TDS were within the $(500 \mathrm{mg} / \mathrm{l})$ highest desirable limit (WHO; 1992)13

\section{Acidity (Acid)}

Acidity is found maximum during winter and minimum during summer. Acidity value $s$ of all sample lies in the ranges of $17.1 \mathrm{mg} / 1$ to $34.2 \mathrm{mg} / 1$. Acidity of water is its quantitative capacity to react with a strong base to designated $\mathrm{pH}$. Value of the acidity is about 200 $\mathrm{mg} / 1$ (Dwivedi and Sonar; 2004)14 and observed value are far less than this, indicating that acidity of sample water is a safe range.

\section{Alkalinity (Alk)}

Total Alkalinity shows seasonal variation in the study . ALklinity value ranges from $224 \mathrm{mg} /$ 1 to $284 \mathrm{mg} / 1$. The value we re high during the summer and low during winter. The fall in values during monsoon may be due to dilution of water.The high value of alkalinity indicates the presence of weak and strong base such as carbonate and hydroxide in the water body (Jain et al ; 2002) ${ }^{15}$, (Abhasi et al; 1999) ${ }^{16}$.

\section{Carbon Dioxide}

The carbon di oxide level fluctuated be tween $1.8 / 1$ to $2.5 \mathrm{mg} / 1$. The seasonal value were 3.82 $\mathrm{mg} / 1$ in winter, $2.27 \mathrm{mg} / 1$ in summer and 3.22 $\mathrm{mg} / 1$ in rainy season. Low value of free $\mathrm{CO}_{2}$ as observed during summer are mainly because of $\mathrm{CO}_{2}$ is utilized in the polysynthetic activities. The concentration increases in rainy season, because rate of photosynthesis being low due to cloudy weathe $\left(\right.$ Sharma et al; 2004) ${ }^{17}$.

\section{Dis solve Oxygen (DO)}

The dissolve oxygen is most important factor in fresh water life. In present study DO is ranged between $3.4 \mathrm{mg} / 1$ to $4.3 \mathrm{mg} / 1$. The ave rage DO value were $3.56 \mathrm{mg} / 1$ in summer, $4.05 \mathrm{mg} / 1$ in winter and $3.95 \mathrm{mg} / 1$ during rainy season The value of DO was obtained as following order, winter $>$ rainy $>$ summer season in present study. The result are similar and co related with investigation. The phenomenon of re-oxygenation of water during monsoon may be due to the circulation and mixing by in flow water monsoon rains (Hannam; 1979) ${ }^{18}$. It further $r$ progressed in winter may be due to the circulation by cooling and draw down the DO in water.

\section{Total Hardness (TH)}

The total hardness of river water in jagatungasamudra from Kandhar, Dist- Nanded (MS) noted the total hardness of bore w Jagatungasamudra from Kandhar, Dist- Nanded (MS)11 water samples of Bhiloda taluka region North Gujarat ranged from 3.1 to $12.3 \mathrm{meq} / \mathrm{L}$. 
The lowest value was recorded from Sunokh and the highest value from Kebava. The values of total harden of $77 \%$ samples are within the permissible range i.e. $30 \mathrm{mg} / \mathrm{L}$. The higher values of hardness clearly indicate that the river water is very hard and is unfit for consumption and domestic use in washing and cleaning. Hiware et. al., (2004)19 recorded the total hardness of water.

\section{Chloride (C1)}

The chloride of the Hindan river water near East Delhi and Sahibabad varied from 22 to 40 $\mathrm{mg} / \mathrm{L}$. The higher values were attributed to industrial effluents and sewage. The chloride concentration of Karamnariver in

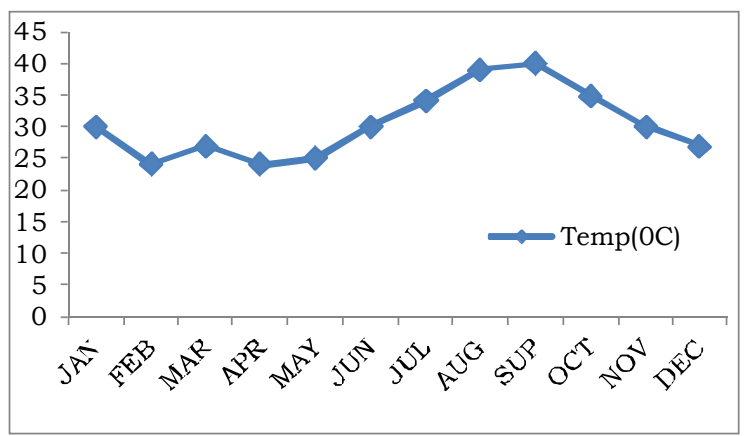

Graph 1.Atmos pheric Temperature $\left({ }^{\circ} \mathrm{C}\right)$,

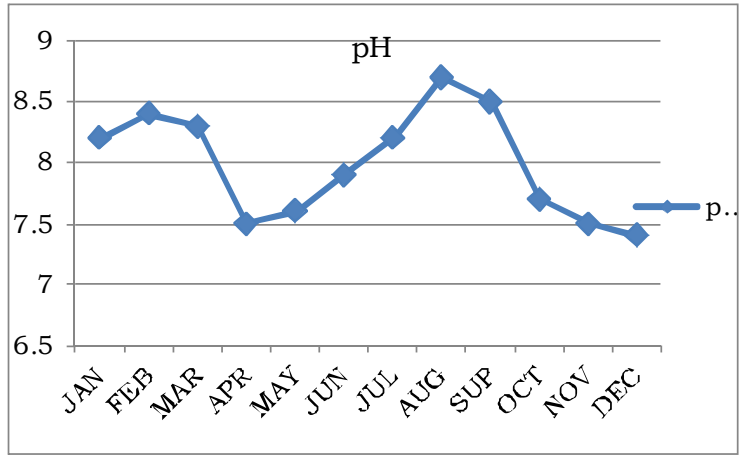

Graph:3. pH,

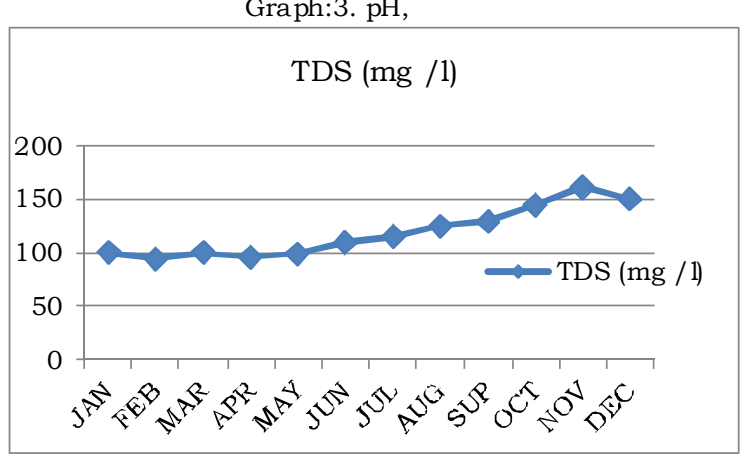

Graph:5. Total Dissolve Solid (TDS)
Thiruvananthpuram district, South Kerala ranged from 1.2 to $15.807 \mathrm{mg} / \mathrm{L}$. The higher chloride recorded during pre-monsoon may be due to inflow of sewage (Jayaramanet. al., 2003) 20 .

\section{Acknowledgements:}

We are thankful to the professors and principal of D.P.R.College Adinathnagar to providing laboratory and library facilities. I also thanks to my family member and my frie nds to encouragements and co-operation during completion of this work.
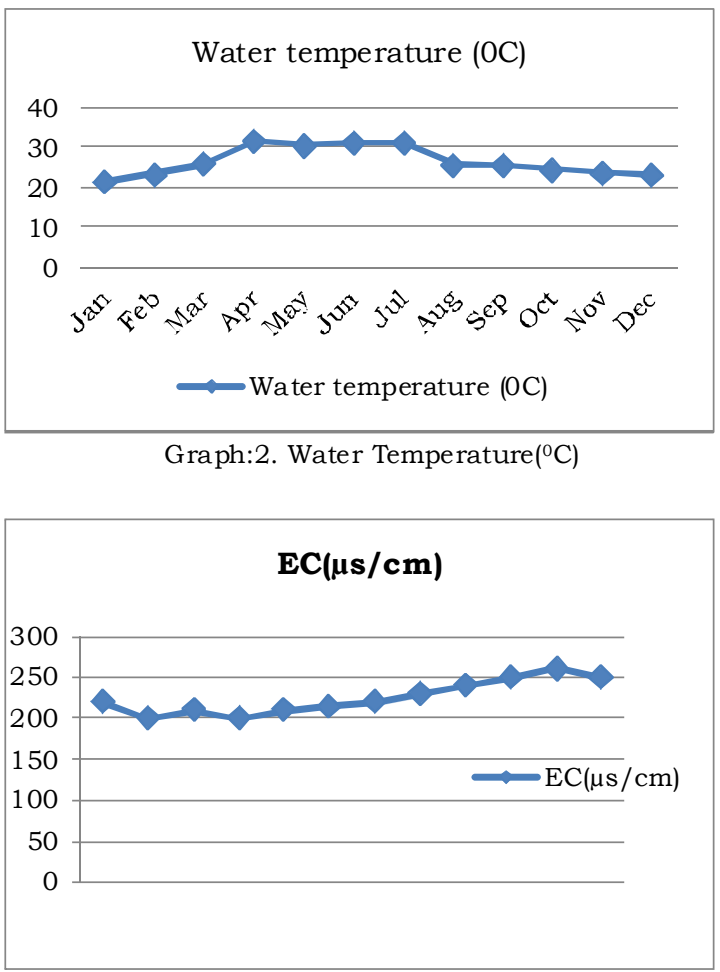

Graph:4. Electrical Conductivity (EC)

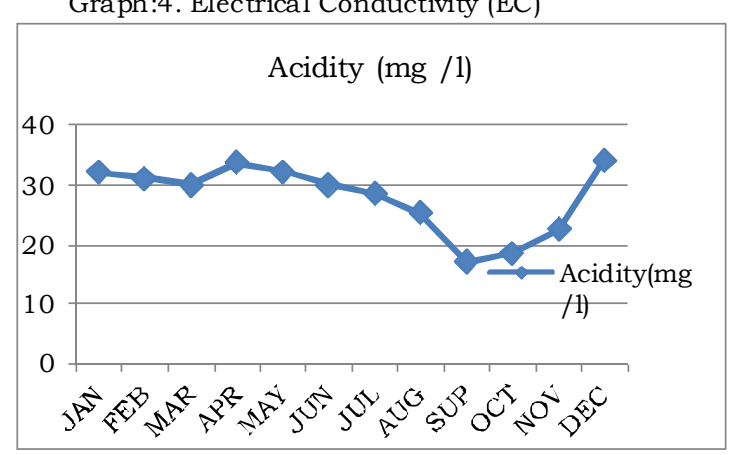

Graph: 6. Acidity (Acid) 


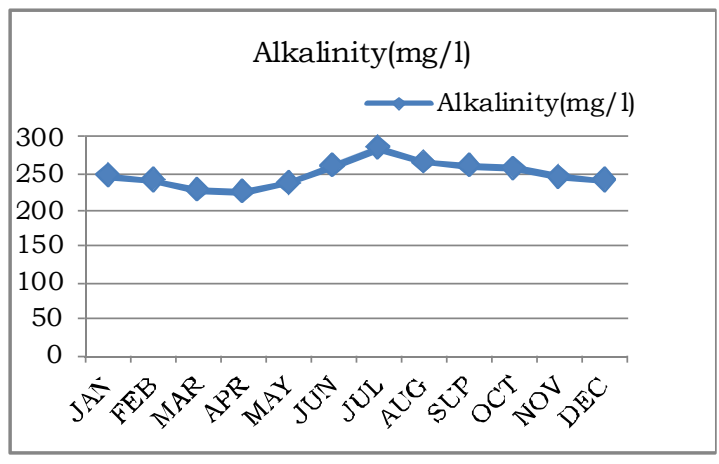

Graph:7 : Alkalinity (Alk)

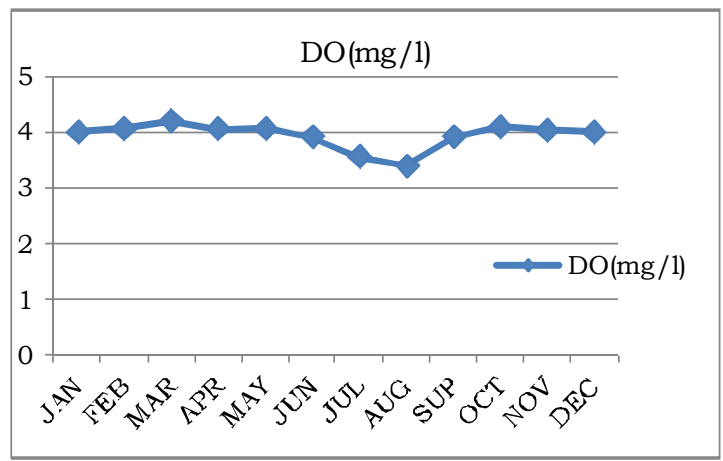

Graph:9. Dissolve Oxygen (DO)

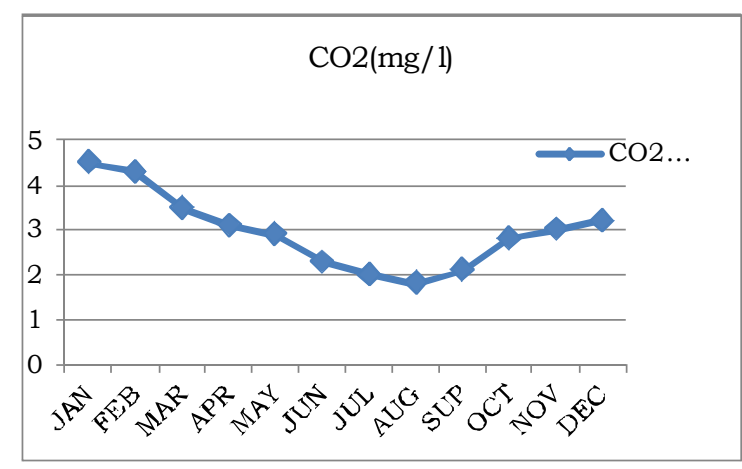

Graph:8. Carbon dioxide $(\mathrm{CO} 2)$

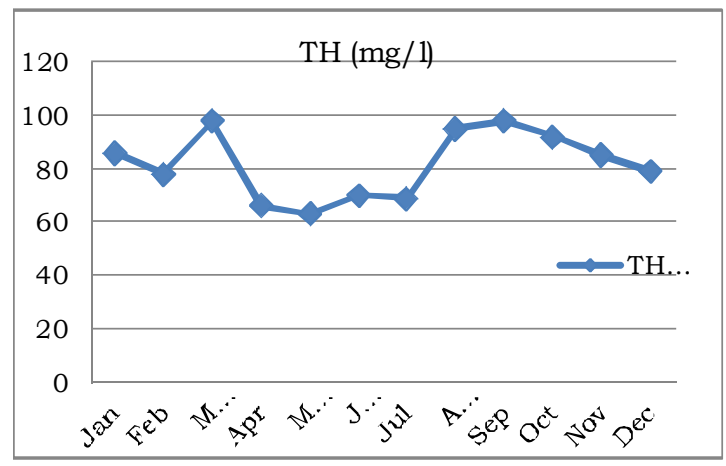

Graph:10: TH

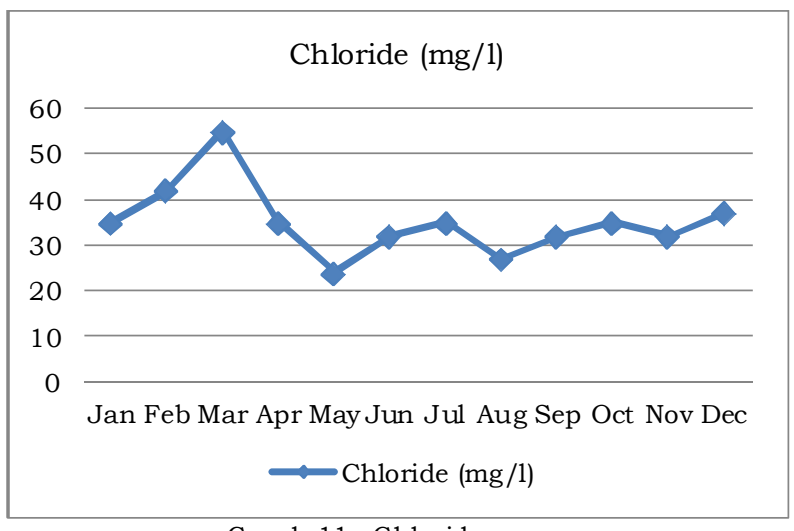

Graph:11: Chloride

\section{Refer ences}

Abhasi. S.A. and VinithanS (1999): Studies on water quality in and around on industrial disturb of Pondicherry. Indian j. Env.Hith.41(4) : Pp.253263.

Chandrasekhar J. S., K. L. Babu\& R. K. Somasekar, (2003): Impact of urbanization on Bellandur Lake, Bangalore - A case study, J. Environ. Biol. 24 (3): pp.223-227.

Dwivedi, P.and Sonar., (2004): Evaluation of physiological and characteristics of water sample in water reservoir around Rono Hills, Doimukh (Dist.Papumpare) Arunachal Pradesh. Poll. Res 23(1): Pp. 101-104.

Goel, P.K., (1997): Water Pollution causes, Effects and control, New Age international publishers. New Delhi: pp: 143-149.
Haniffa, M. A., S. Arockiasamy\& P. Martin., (1993):Physico-chemical and microbiological studies in the Perenial River Thabaraparani for the Envior.Sci.6: pp. 97-116.

HannamH.,(1979): Chemical modification in reservoir regulated Streams In: The ecology of regulated streams (Eds) Ward, J.W. and Stanford, J.A. Edition plenum corporation publication. (5):Pp.75-94.

HiwareC.J. UgaleB.J. and Walunjkar A.G.,(2004): Studies of some physiochemical characteristics of jagatungasamudra from Kandhar, Dist- Nanded (MS). Nat. J. of Life Sci.1(1): pp. 73-75.

Jain, C. K., D. C. Singhal\& M. K. Sharma., (2002): Survey and characterization of waste effluents polluting river Hindon, Indian J. of Envtl. Prtcn. 22(7): pp. $792-799$. 
Jain, S., S. K. Gupta \& S. Salman, (1995): Seasonal changes in heavy metals in water and sediment of a Eutropic Lake, Indian J. of Envtl. Prtcn. 16 (3): pp. 197-202.

Jayaraman, P. R., T. G. Devi \& T. V. Nayar., (2003): Water quality studies on Karamana River, Thiruvananthapuram District, South Kerala, India, Poll. Res. 22 (1): pp.89-100.

Maiti, D., Kole, R.K. and Das, D.K., (2006): Occurrence of Various metals in Surface water of River Ganga in west Bengal. Their toxicity and Ecological impact. Poll. Res. 25(3). pp: 609-612.

Radhika C. G., I. Mini \& T. Gangadevi, (2004): Studies on abiotic parameters of a tropical fresh water lake - Vellayani Lake, Trivandrum, Kerala, Poll. Res 23(1): pp.49-63.

Shankar P.Jayaraman, P.R. and Gangadevi T., (2002): Studies on the Hydrography of the lotic ecosystem 'Killiar' Thiruvan thapuram, Kerala. In dia Poll.Res J.21 (2): pp.113-12 1.

Sharma L. L. \& N. Sarang, (2004):Physico-chemical limnology and productivity of Jaisamand Lake, Udaipur (Rajasthan), Poll. Res. 23(1): pp.87-92.
Sharma L. L. \& N. Sarang, (2004):Physico-chemical limnology and productivity of Jaisamand Lake, Udaipur (Rajasthan), Poll. Res. 23(1): pp.87-92.

SinghaiS.RamaniG.M. and Gupta., U.S.,( 1990): Seasonal variation and relationship of different physiochemical characte ristics in newly made Tawa Reservoir. Limnio logical (Berlin). Res $J 21$ (1):pp. 293-301.

Trivedi,R.K. and GoeP.K. (1986). Chemical and biological methods for water pollution studies. Environmental publications, Karad (India).

TrivediR.K., (1995): Sources of water pollution and water quality Parameters, Encyclopedia of environmental pollution and Control (Ed. By Trivedy, R.K.) En viron media Karad.

WHO, (1992): Our planet our health-report of the WHO commission on health and Environment, Published by WHO, Geneva: pp. 130-131.

Zafar, A.R. (1966): Limnology of Hussiansagar Lake, Hyde rabad. India phykas, (5): pp.115-126. 